This item was submitted to Loughborough's Research Repository by the author.

Items in Figshare are protected by copyright, with all rights reserved, unless otherwise indicated.

\title{
Advancing our understanding of the EU sports policy: the socio-cultural model of sports regulation and players' agents
}

\section{PLEASE CITE THE PUBLISHED VERSION}

https://doi.org/10.1080/19406940.2018.1432671

\section{PUBLISHER}

(C) Taylor \& Francis

\section{VERSION}

AM (Accepted Manuscript)

\section{PUBLISHER STATEMENT}

This is an Accepted Manuscript of an article published by Taylor \& Francis in International Journal of Sport Policy and Politics on 18 Apr 2018, available online: https://doi.org/10.1080/19406940.2018.1432671

\section{LICENCE}

CC BY-NC-ND 4.0

\section{REPOSITORY RECORD}

Yilmaz, Serhat. 2019. "Advancing Our Understanding of the EU Sports Policy: The Socio-cultural Model of Sports Regulation and Players' Agents”. figshare. https://hdl.handle.net/2134/28470. 
Advancing our understanding of the EU sports policy: the socio-cultural model of sports regulation and players' agents

Serhat Yilmaz

School of Sport, Exercise and Health Sciences, Loughborough University, Loughborough, $U K$

s.yilmaz3@lboro.ac.uk 


\title{
Advancing our understanding of the EU sports policy: the socio-cultural model of sports regulation and players' agents
}

\begin{abstract}
This paper explains the development of the socio-cultural dimension of the European Union (EU) sports policy over the course of the decade from 2005 to 2015. By adopting the theoretical lenses of the Advocacy Coalition Framework (ACF), the paper firstly offers a novel perspective on the belief systems of the members of the socio-cultural advocacy coalition that operates within the EU sports policy subsystem. A set of empirical policy core beliefs of the coalition actors reflecting their concerns regarding to sport's integrity and economic welfare that affect its healthy development is presented and explained as the basic causes of the policy problem, i.e., threats that undermine sport's specific characteristics. In this light, the paper then illustrates that the coalition members have perceived the issue of players' agents, in particular problems in the activities of agents in European football, to be detrimental to the integrity of sport. As a result, the issue has been the subject of a considerable policy activity by the coalition actors with a view to establishing an alternative regulatory framework to effectively govern players' agents. Consequently, the paper elucidates the evolving nature of the socio-cultural model of sports regulation that not only promotes the social role of sport in Europe but now also addresses the problems that affect its well-being and clear image. The paper's principal method of investigation is based on the content analysis of official policy documents and statements of the coalition actors.
\end{abstract}

Keywords: Intermediaries; integrity of sport; the Advocacy Coalition Framework; the sociocultural advocacy coalition; EU sports policy; specificity of sport

\section{Introduction}

European Union (EU) sports policy has a dual nature. On one hand, the EU pursues regulatory objectives that are underpinned by its commitment to the legal foundations of the single market and aim to correct market failures of sport governing bodies. On the other hand, there are political policy objectives that intend to protect and promote sport's specific characteristics such as its socio-cultural values and unique organisational aspects with a view to enhance its social role in Europe. Yet, the academic literature on the EU sports policy features a strong regulatory bias (Geeraert and Drieskens 2015) and the intervention into sport by the EU is predominantly analysed from a legal perspective to explain the application of EU law to sport (Caiger and Gardiner 2000, Bogusz et al. 2007, Gardiner et al. 2009, Duval and Van Rompuy 2016). This approach, however, neglects the political dimension of the policy and, coincidently, a scarce but a significant body of theoretical work that elucidates the evolving dual nature of the EU's approach to sport (Parrish 2003a, 2003b, Garcia 2007, 2008, Geeraert and Drieskens 2015, 2017) has been rather underutilised. Nonetheless, there is now a growing recognition that the analysis of the EU's legal intervention hardly captures the full extent of its relationship with sport (Garcia and Meier 2016) and, more importantly, fails to explain the new realities of sport policy making in the post-Lisbon era during which, for the first time, the EU enjoys a formal authority in the field of sport (Geereart 2014). For these reason, it is necessary to bring the focus of analysis back 
onto the political dimension of the EU sports policy in order to explore its explanatory powers for policy development in Europe.

This paper aims to explain how the political strand of the EU sports policy has progressed over the period of a decade from 2005 to 2015. In doing so, it draws on Parrish's theoretical insight on the development of the sports policy in Europe (Parrish 2003a, 2003b). Parrish conceptualised the political dimension of the policy as the translation of the belief system of 'the socio-cultural advocacy coalition' that operates within the EU sports policy subsystem and defined it as 'the socio-cultural model of sports regulation' (Parrish 2003a, p. 69, Parrish 2003b, p. 251). Through the same line of enquiry, this paper firstly examines and explains the way the socio-cultural regulatory model and the coalition have evolved since Parrish's original work in 2003. It then investigates the activities of the members of the socio-cultural advocacy coalition in relation to a specific policy issue; players' agents (now known as 'intermediaries') to elucidate the evolving nature of the socio-cultural policy making in Europe.

In this respect, the issue of players' agents offers an adequate context for policy analysis. It has been a dominant policy item within the EU political agenda from 2005 until the adoption of a new regulatory framework by the Fédération Internationale de Football Association (FIFA) in 2015. During this period, the key policy actors of the socio-cultural advocacy coalition have engaged in activities concerning players' agents. However, the issue was previously in the hands of the rival coalition of the subsystem, the single market advocacy coalition, during the period from 1998 to 2005. This initial incursion of the EU was concerned with the restrictive elements of FIFA's original Players' Agents Regulations adopted in 1994 under which a licensing-based regulatory system was established requiring a license to access to the agent profession. The conformity of the license requirement with EU law was questioned and argued that the system constituted a restriction to operate as a players' agent and eliminated competition in the internal market (Branco Martins 2007, Rossi et al. 2016). In 2005, the General Court confirmed the rule making power of FIFA over agents and the compatibility of its licensing system with EU law (Branco Martins 2009). So, despite the ruling, why was the issue of players' agents shifted into the EU's political agenda? What has motivated the intervention of the members of the socio-cultural advocacy coalition into the issue at the European level? What specific policy actions have the coalition actors taken regarding to the issue since the judgment of the General Court? By exploring these questions, the paper intends to offer a critical insight into the development of the socio-cultural dimension of the EU sports policy and its evolving nature.

Through adopting the theoretical lenses of the Advocacy Coalition Framework (ACF), this paper develops a novel perspective on the belief systems of the members of the socio-cultural advocacy coalition to explain the evolving nature of the political dimension of the EU sports policy. It firstly presents a set of empirical policy core beliefs of the coalition actors that reflects their concerns about the integrity of sport and its economic welfare which are both fundamental for the healthy development of sport and its specific characteristics, including its socio-cultural qualities, in Europe. The paper also explains that the socio-cultural model of sports regulation now manifests itself in a policy framework that is based on a thematic policy agenda with priority issues and specific policy actions aiming not only to promote sport's socio-cultural values but also to tackle its problems that affect its well-being. Then, through its issue-specific analysis, the paper elucidates that the issue of players' agents, in particular problems in the activities of agents in European football, has been considered to be a challenge that is detrimental to the integrity of sport. As a result, the issue has become the 
subject of policy activities by the members of the socio-cultural coalition over the course of the decade from 2005 to 2015.

The utilisation of the ACF allows the paper to analyse the relationship between policy-related beliefs, actions and outcomes on the same canvas. In this regards, the ACF differs from the agenda-setting model that used by Garcia $(2007,2008)$ and the principal-agent model that adopted by Geeraert and Drieskens (2015) for the analysis of the sports policy in Europe as both frameworks are a process driven heuristic model. Whereas, the ACF enables to develop an ideational focus to explain and examine cognitive forces, i.e., beliefs, as the main driver of policy process. Additionally, the ACF helps the paper to build upon the Parrish's theoretical insight related to the formation, the composition, and the belief system of the socio-cultural advocacy coalition. The approach provides a continuum for the theoretical study of the EU sports policy, yet offers an opportunity for issue specific analysis within the same policy subsystem, i.e., the sports policy subsystem. This also permits the paper to develop a holistic view of the policy.

The paper will proceed in four steps. First, the key components of the ACF that are central for the analysis of the paper are outlined. Second, the evolved composition of socio-cultural advocacy coalition, including key members, their belief systems, and resources, is explained. Then, the analysis of socio-cultural policy making in Europe concerning the issue of players' agents is presented. Finally, the paper reflects upon its findings and highlights the implication for our understanding of the EU sports policy in general. The principal method of investigation is the documentary content analysis of primary literature of policy documents and statements by the members of the socio-cultural advocacy coalition. The content analysis of official publications is considered to be the most adequate methodological approach to examine the beliefs and policy positions of the cluster of policy actors over periods of a decade or more (Sabatier and Jenkins-Smith 1993). Academic work on the EU and sport as a secondary literature is also examined for the purposes of the paper.

\section{The Advocacy Coalition Framework}

The ACF is a complex theoretical tool kit and this section outlines its key concepts and the depicted casual process that are utilised for the analysis of the socio-cultural policy making in the paper's following sections.

Policy core beliefs: The ACF conceptualises public policies as belief systems involving value priorities, perceptions about important casual relationships, the magnitude of the problem, and the efficacy of various policy instruments (Sabatier 1988, 1998). The framework therefore develops a hierarchical tripartite belief system (deep core beliefs-policy core beliefs-secondary beliefs) which is a fundamental characteristic of its model of individual (Sabatier and Weible 2007, Jenkins-Smith et al. 2014). The ACF postulates that the primary motivation of rational policy actors of a specific subsystem is to translate their policy core beliefs into actual policies (Sabatier 1988). Policy core beliefs are defined as 'fundamental policy positions concerning the basic strategies for achieving core values within the subsystem' (Sabatier and Jenkins-Smith 1999, p. 133). In terms of their scope, policy core beliefs span the entire policy subsystem and apply all aspects of the policy (Sabatier and Weible 2007). In terms of topic, the ACF identifies eleven categories of policy core beliefs (Sabatier and Jenkins-Smith 1999). Normative policy core beliefs are the translations of an individual's fundamental value priorities in deep core beliefs. Empirical policy core beliefs, 
on the other hand, are made up of perceptual components including the overall seriousness of the policy problem, its basic causes, and the priority that must be given to various policy instruments which informs the secondary aspects of the individual's belief system regarding instrumental decisions to tackle the problem (Sabatier and Jenkins-Smith 1999). Policy core beliefs also act as a driver, guiding political behaviours of policy actors, and as a cognitive constraint, filtering the way in which actors perceive and process reality (Weible 2005, Matti and Sandstrom 2013). The perceptual filtering means that policy advocates with noncorresponding policy core beliefs subsequently interpret the same piece of information differently and reach divergent conclusions which push them apart (Henry 2011). The situation also breeds distrust to produce 'the devil shift' effect to treat opponents with a great suspicion (Sabatier and Weible 2007, p. 194). As a result, the ACF assumes that policy actors coordinate their activities only with others who hold similar policy core beliefs and they together form advocacy coalitions (Jenkins-Smith et al. 2014). Therefore, shared policy core beliefs are pivotal for the formation of coalitions with policy subsystems.

The role of policy analysis in the actual policy process: The translation of policy core beliefs into the public policy requires coalition actors to understand problem parameters such as its root causes and effecting factors and also the efficacy of various policy interventions to tackle it (Sabatier and Jenkins-Smith 1993). In practice, as a result, the public policy process involves the analysis of specific issues/problems that affecting the policy core, 'threats to core values' (Jenkins-Smith and Sabatier 1993, p. 45), and the search of related information to comprehend the extent of their impacts. This understanding of the role of policy analysis in the actual policy process is important to explain the recognition of a specific issue as a policy problem, its inclusion into the policy agenda, and related specific actions to address it (Sabatier and Jenkins-Smith 1993). The issues that are perceived to be impacting on the core values therefore attract the attention of coalition actors. Consequently, the policy analysis enables policy advocates to learn about these problem parameters and factors affecting them and also understand the ways to tackle them with specific policy instruments (Sabatier 1993). At the end of the policy process, public policy is formulated which produces policy outputs at operational level (Sabatier 1993). These outputs produce a variety of impacts on targeted problem parameters with an aim to protect the policy core.

Resources: The policy process depicted above which involves the analysis of specific policy issues as problem parameters and the development of instrumental preferences to tackle them underlines the importance of resources of coalitions within the subsystem. The coalition actors cooperate to exploit coalition resources to influence the policy in line with their shared policy core beliefs (Jenkins-Smith et al. 2014). The category of resources that is postulated by the ACF includes formal legal authority to make policy decisions, information, public opinion, mobilisable troops, financial resources, and skilful leadership (Sabatier and Weible 2007). In the process of learning related to a specific policy issue, information is a particularly important resource of the coalition allowing policy actors to understand to the extent to which given situation affects their values, i.e., their policy core beliefs (JenkinsSmith and Sabatier 1993). Technical information related to the severity of issues, the ways these issues constitute affecting factors in relation to the policy core, and the cost and advantage of policy alternatives enables policy actors to make informed decisions (Barke 1993). The formal legal authority for policy decisions is another important resource for advocacy coalitions to be able to formulate the policy that addresses the policy problem, or, in other words, the issues that affecting the policy core. Without such authority, coalitions' ability to affect the policy is limited (Weible 2006). For this reason, policy actors with the formal legal authority for the policy are generally deemed to be the key members of advocacy 
coalitions and also an important feature of dominant coalitions within policy subsystems (Jenkins-Smith et al. 2014). Nonetheless, the ACF also underlines exogenous factors that affect policy subsystems and can constrain the resources of the coalitions. In particular, the constitutional settings of subsystems can directly affect the legal authority for making policy decisions and restrict the range of feasible instrumental alternatives impacting on the secondary aspects of actors' belief systems (Sabatier 1988).

Coordinated activity: Finally, in the course of the ACF's depicted policy process, the activities by coalition actors on a specific policy issue need to be in a structured manner. Because, the existence of advocacy coalitions requires a non-trivial degree of coordinated activity and 'if there is no coordinated behaviour, there are no advocacy coalitions' (Zafonte and Sabatier 1998, p. 479). Coordination is deemed to involve 'some degree of working together' (Sabatier and Weible 2007, p. 196) by coalition actors and implies cooperation and supporting activities such as developing a joint strategy or a synchronised shared action in order to materialise their policy goals (Weible and Sabatier 2005). The ACF distinguishes between different levels of coordination as the intensity of involvement by policy advocates in the subsystem varies (Zafonte and Sabatier 1998, Stritch 2015). A weak form of coordination involves the element of interactions amongst actors and the exchange of information concerning problem parameters, yet not comprise any elaborate decision making or the monitoring of the process (Stritch 2015, Jenkins-Smith et al. 2014). In practice, this level of coordination can still have a significant impact on the actual policy because the information exchange as a result of repeated interactions allows coalition actors to learn about policy issues that affect their core values and to develop common understanding about them (Sabatier and Jenkins-Smith 1993, Sabatier and Jenkins-Smith 1999). A strong form of coordination, on the other hand, requires conditions beyond repeated interactions and the information exchange and involves more onerous activities such as joint research and policy analysis, a joint funding of advocacy cost, and participation in meetings to discuss strategies and tactics (Matti and Sandstrom 2013, Stritch 2015).

\section{The socio-cultural model of sports regulation and the issue of players' agents}

\section{The socio-cultural advocacy coalition}

The socio-cultural advocacy coalition is originally conceptualised by Parrish in his theoretical work on the development of the EU sports policy (Parrish 2003a, 2003b). Parrish systematically analysed and outlined the origins of the coalition including its membership structure and the historical discourse of its policy activities from 1980s until the Nice Declaration in 2000. The coalition has a 'complex composition' with a several policy actors from both the EU institutions and sport itself (Parrish 2003a, p. 68). However, because the intensity of the actors' involvement into the policy subsystem varies, the paper focuses on those members who have been actively engaged in the policy process concerning the issue of players' agents. They are the Directorate General for Education and Culture (DG EAC), the European Parliament's Committee on Culture and Education (CULT), and the most of the Member States (hereafter together referred as 'the EU policy actors') that operate at the EU institutional level and FIFA and Union of European Football Associations (UEFA) from the world of football (hereafter together referred as 'the sport actors').

According to Parrish (2003a, 2003b), the policy core beliefs of the coalition actors reflect their desire to protect and to promote sport's specific characteristics that encompass its socio- 
cultural qualities and unique structural features including its autonomy and organisational diversity. Although Parrish did not offer any categorical distinction of the policy core beliefs, it was acknowledged that not all members of the coalition share similar deep core beliefs about the promotion of positive European integration (Parrish 2003a, p. 68). This means that normative policy core beliefs of these actors related to the specificity of sport diverge; the EU policy actors value the socio-cultural role of sport for European society whereas the autonomy of sport is vital for the sport actors. Nevertheless, the actors share common empirical policy core beliefs that reflect their perceptions about the basic causes of the policy problem, i.e., threats to their normative core values. Historically, the perceived common threat has been the prevailing market-based definition of sport adopted by the competing single market advocacy coalition which has enabled the application of EU law to the rules and practices of sport. Therefore, the original unifying force of the socio-cultural advocacy coalition was 'a desire for sport to be exempt either partially or fully from EU law' (Parrish 2003b, p. 250) and 'the socio-cultural model of sports regulation' (Parrish 2003a, p. 69) that promotes its unique characteristics. By working together within the subsystem, the coalition actors had managed to re-define sport as a socio-cultural activity (Garcia 2007) and the EU sports policy was re-directed towards the socio-cultural regulatory model (Parrish 2003a, p. 197). These actors were also instrumental for the attainment of competency on sport through the incorporation of the Treaty provision originally into the unratified Treaty establishing a Constitution in 2004 which eventually found its way into the Lisbon Treaty (Garcia and Weatherill 2012). In this respect, for the first time, the supporting and complementary competency now allows the EU policy actors of the coalition to develop a formal sports policy with a dedicated budget line and favours the autonomy of the sport actors by requiring the EU actions to take sport's specific nature into account.

The origins of the socio-cultural advocacy coalition that are presented above, however, only helps to explain the half of the story. Understanding the way the socio-cultural regulatory model of sport has progressed since late 2004 following the incorporation of the sport text into the final draft of the Treaty establishing a Constitution requires the socio-cultural advocacy coalition to be brought up to date. In this respect, it is important to understand that the congruent empirical policy core beliefs of the coalition advocates are complex. Their perceptions about the basic causes of the policy problem are not limited to the economic definition of sport adopted and facilitated by the rival single market coalition but also include concerns about sport's well-being and healthy development in Europe. These precepts are especially related to the integrity of sport and its sustainable economic growth that directly affect its welfare in Europe. For the EU policy actors, the clean image of sport and its sustainable development are particularly important for its social role in European society. The integrity of sport is central for its credibility and attractiveness affecting the public's confidence and trust in its positive values. A good financial state of sport directly contributes to the macro-economic objectives of the EU by positively affecting the growth in the European economy while also supporting infrastructures and grassroots sports through its redistribution and solidary mechanisms. These perceptions are directly discernible within a number of policy documents that emerged over the course of the decade since 2005 (European Commission 2007a, 2011a, European Parliament 2007a, 2008, 2012, Council of the European Union 2011, 2014). The healthy development of sport is equally important for the sport actors who share similar concerns about its integrity and economic welfare. In particular, the failure to protect sport from the negative trends is perceived to be a problem in the governance of sport which brings the autonomy enjoyed by the sport actors into question and this is not in their best interest (Geeraert et al. 2013). These perceptions of the governing 
bodies of football are also evident in a number of documents and statements (FIFA 2007, 2009a, 2014 UEFA 2005, 2007a, 2008a, 2010). Consequently, these common perceptions concerning the healthy development of sport have been the unifying force of the coalition over the course of the last decade and shaped the activities of the coalition actors within the subsystem with a view to safeguard sport from the detrimental impacts of its negative developments.

The secondary aspects of the coalition actors' belief systems, during the period from 2005 to 2015, have therefore reflected their instrumental preferences that not only promotes specific characteristics of sport including its socio-cultural values and autonomy but also protects the integrity and financial well-being of sport for its healthy development. In this connection, the EU policy actors have been developing a socio-cultural oriented policy framework based on a thematic agenda with priority issues and related actions and outputs. The prioritised issues of this framework are perceived to be specific problem parameters that affect the clean image of sport and its financial health, thus threaten the policy core. For this reason, the policy framework aims to produce outputs that target these root causes of the policy problem. As a result, the specific policy issues such as doping, match-fixing, minors, corruption as well as players' agents that are considered to be negatively affecting the integrity of sport and the issues such as the sustainable financing of grassroots sport, the financial solidarity structures, the legacy of major sports events, and the evidenced-based policy making that are perceived to be impacting on the economic health of sport have been dominating the EU political agenda and seen a serious advocacy activity over the course of the last decade. In this respect, the White Paper on Sport in 2007, in the anticipation of the new competency under the Lisbon Treaty which came into power in 2009, was the first comprehensive policy initiative that established the framework (Rogulski and Miettinen 2009). It has then been formally implemented by the subsequent Council resolutions on the EU Work Plan on Sport (Council of the European Union 2011, 2014, 2017) in the aftermath of the Lisbon Treaty (Geeraert 2016). This policy framework also ensures a strengthened cooperation structure between the EU policy actors because of the aligned priorities but also promotes a closer working relationship with the sport actors via the structured dialogue at the European level (Council of the European Union 2010).

The policy framework has been also supported by the coalition's sport actors because their preferences favour a model based on a public-private partnership that respects their autonomy and supports their efforts to overcome the challenges that sport faces. In this regard, the assistance of public authorities to tackle the criminal aspects of some of the problems that affect the integrity of sport is particularly important for these actors due to their limited capabilities in policing and sanctioning (UEFA 2008a, FIFA 2009a). The sport actors also require help in protecting their income sources, for instance the exploitation of intellectual property rights such as licensing of broadcasting rights and merchandising, from illegal activities through a greater regulatory control by public authorities which is also important for the financial health of sport (UEFA 2008a). Therefore, collaborative ties that have been developed within the subsystem, in effect, ensure that these actors work together towards similar policy objectives. Hence, the sport actors have been aligning their priorities in line with the EU political agenda over the course of the last decade to guarantee that related policy actions are coordinated and structured (UEFA 2008a, 2010, IOC 2010).

Meanwhile, stakeholders representing different interest groups are the contemporary actors that have emerged within the subsystem and developed close ties with the socio-cultural coalition over the course of the same period. The stakeholders are also diverse including pan- 
European organisations representing the interest of clubs, leagues, athletes, supporters and economic entities. The paper focuses on those that operate in European football and have actively involved in the policy process concerning players' agents. They are the European Club Association (ECA) as the representative body of European football clubs, the Association of European Professional Leagues (EPFL) as the group of European major leagues, The Fédération Internationale des Associations de Footballeurs Professionels (FIFPro) as the umbrella organisation for national players associations, and the European Football Agents Association (EFAA) as the representative of the national agents' associations in Europe (hereafter together referred as 'the stakeholders'). The belief systems of the stakeholders reflect both economic and social vision of sport. Parrish (2011) argued that these actors incline towards the market-based definition of sport and their policy core beliefs reflect their desire for EU law to protect the interests of their members from the regulatory restrictions of the governing bodies and to afford them a greater representation within the governance of sport. However, perceptions concerning the social role of sport and its healthy development are also important to the beliefs of these actors. These socio-cultural tendencies are discernible within the memorandum of understandings they respectively signed, the FIFPro in 2007 (UEFA 2007b), the EAC in 2008 (UEFA, 2008b), the EPFL in 2009 (UEFA 2009), with UEFA. They have all agreed to closely work with UEFA, FIFA and the EU policy actors to address some of the key issues and challenges affecting sport in Europe. Moreover, a close cooperation at European level serves well for the interests of these actors too. It empowers them with a greater representation within the subsystem, and effectively in the governance of sport, to raise their concerns and to express their positions regarding to issues that affecting their members. The greater representation in turn helps them not to resort to the use of litigation all the time which can be costly and time consuming with the uncertainty of desired outcomes. In this respect, for instance, the EU sectoral dialogue committee in professional football, established in 2008, has been a primary common working platform for the ECA, the EPFL, FIFPro, UEFA and FIFA, under the auspices of the DG EAC, to resolve their differences regarding employment relationships in European football and to conclude agreements (Parrish 2011, Geeraert et al. 2013). Additionally, the requirement for representation diversity and a broad and balanced participation within the EU strengthened structured dialogue framework in the aftermath of the Lisbon Treaty have enabled the stakeholders to fully engage with the policy process at the European level. As a result, the existence of the cooperation structures has helped the stakeholders to align themselves with the socio-cultural advocacy coalition.

The socio-cultural coalition possesses key resources that have been critical for the coalition members to shape the socio-cultural strand of the EU sports policy in line with their policy core beliefs. The EU policy actors enjoy a formal responsibility for sport within the governance setting of the EU (Beunanno and Nugent 2013). Thus, they hold an important coalition resource; the legal authority to make policy decisions. The Commission plays a greater role in setting the agenda and formulating the policy due to its exclusive right to policy initiatives. The European Parliament and the Member States via the Council of European Union benefit from the co-decision making authority under the ordinary legislative procedure with regards to the adoption of policy proposals and the exercise of oversight for the implementation (Wallace et al. 2015). During the pre-Lisbon era, the lack of competency in the field of sport meant that this authority was exercised by the EU actors through the use of soft law instruments, i.e., non-binding measures, (Parrish 2003b, Takorski et al. 2004, Geeraert 2016). The authority is now formalised through the Treaty provision on sport under the Lisbon Treaty (Parrish et al. 2010). The creation of the Sports Ministers' Council within the configuration of the Council allows the Member States to formally develop the socio- 
cultural policy framework through resolutions, although the legal authority is limited to the adoption of recommendations and incentive measures (Parrish et al. 2010). The DG EAC has been exercising its right to initiative through publishing communications, adopting the White Paper on Sport, and financing sport related projects and studies. The CULT Committee has used its power to adopt opinions, reports, and resolutions, to submit parliamentary questions to the Commission, and organise hearings on sport related matters. The sport actors and the stakeholders possess another key coalition resource within the subsystem; information. These actors have provided technical information about problem parameters that affect sport. Such information is vital for the policy formulation and the determination and design of policy outputs. Information has been gathered via the structured dialogue within the subsystem involving consultations, bilateral meetings, conferences, and the EU Sports Forum (European Commission 2007a, 2011a). The interactions of the policy actors also facilitate the diffusion of information to all actors which is consequently essential for their collective learning.

With this novel understanding of the socio-cultural regulatory model and the coalition is in mind, the remaining parts of this paper focus on the activities of the coalition members concerning the issue of players' agents. The analysis aims to inform our renewed understanding that was presented in this section.

\section{The activities of the coalition actors concerning the issue of players' agents}

The discourse of policy making by the coalition actors concerning players' agents can be analysed in three phases.

\section{Phase 1: Pre-White Paper on Sport (2005-2007)}

During this initial stage, the EU policy actors recognised the issue of players' agent as a specific policy problem that affects the integrity of sport and consequently the issue entered into the EU political agenda. Following the Nice Declaration in 2000 and in anticipation of the new competency after the intergovernmental conference in 2004, the EU policy actors, via utilising the soft law instruments, engaged in initiatives to explore the best ways to protect and to promote specific characteristics of sport in Europe. In this connection, a group of European Sport Ministers initiated the European Independent Sport Review (IESR) (Arnout 2006) during the UK Presidency in 2005 to review the issues that affecting football and undermining its social role in Europe (Garcia 2006). At the same time, the DG EAC commenced its work on the White Paper on Sport (European Commission 2007a) by launching a stakeholders consultation in May 2005, titled 'The EU \& Sport: Matching Expectations' (European Commission 2007b, p. 111). The consultation ensured dialogues with the sport actors and the stakeholders with an objective of exchanging views about the negative trends that affect sport in Europe. The Member States unanimously supported the DG EAC's initiative and set up an ad-hoc Working Group 'White Paper' (European Commission 2007b, p. 127) in November 2006 to discuss concrete topics of their interests in order to determine their priorities for the White Paper. The CULT Committee also started working on its report of 'the future of professional football in Europe' to review challenges of European football in order to make its priorities explicit for the White Paper too (European Parliament 2007b).

FIFA, UEFA and the stakeholders, at this stage, played an important role by drawing the attention of the EU policy actors to the issue of players' agents at different dialogue platforms 
and provided information regarding to their situation in European football. These actors repeatedly expressed their concerns about the problems in the activities of players' agents. In particular, dubious practices such as the widespread dealings of unlicensed agents in European player market, the exploitation of young players, and dual representation were all underlined (European Commission 2007b, Arnaut 2006, European Parliament 2007a, 2007b). For example, the issue was discussed during an informal meeting between the Sport Ministers of big five footballing nations in Europe and the representatives of FIFA and UEFA in December 2005. The regulation of players' agents was considered to be among the range of challenges faced by European football and, for this reason, the review team of the EISR was mandated to examine the existing regulatory arrangements that govern the activities of player' agents and to explore potential ways to improve the situation in Europe (Arnaut 2006). The issue was also discussed in a greater detail during the Sport Governance Conference organised by the DG EAC in September 2006 as a part of its stakeholders consultation. Attended by representatives of more than 30 European sport federations and organisations, the meeting provided direct inputs into the White Paper (European Commission 2007b). Some federations identified players' agents as an area for a possible EU action (European Commission 2006, p. 3). The DG EAC also held bilateral meetings with FIFA, UEFA and the stakeholders during which potential issues for the White Paper were analysed (European Commission 2007b). The issue was also one of the 'crucial elements' of report by the CULT Committee and its subsequent resolution (European Parliament 2007c, p. 1). The Committee particularly analysed the findings of the parliamentary working paper, 'Professional Sport in the Internal Market' (European Parliament 2005), and the UK's Stevens Report about the malpractices of agents in English football (European Parliament 2007c, 2007d).

The analysis of players' agents in different platforms and the exchange of information enabled the EU policy actors to learn about their situation in European football and to develop mutual understanding of the issue. In particular, the learning about the problems in the activities of players' agents affected the EU actors' perceptions, especially the way the situation of players' agents negatively impacts on the integrity of sport and undermines the well-being of football and its social function in Europe. The congruent perceptions about causal relationships between the malpractices of players' agents, the integrity of sport, and its social role are discernible from the policy documents that emerged during this period. The Member States viewed the issue as a 'notorious problem' and a pressing concern 'for the efficient administration and financial well-being of football and for the image of the game' (Arnaut 2006, p. 46). In their opinion, there was 'a critical need for more effective regulation of agents in Europe' and 'without this reform football will continue to suffer significant reputation damage' (Arnaut 2006, p. 88). The CULT Committee perceived the issue among the negative spiral of fraudulent practices in European football and underlined the need to protect 'the important social and educational role of football' from its harmful impacts (European Parliament 2007d, p. 1). For the DG EAC, the bad practices of players' agents were 'damaging for sport in general and raise serious governance questions' (European Commission 2007a, p. 15) and needed to be fought for to protect the integrity of players, particularly young ones (European Commission 2007b). Consequently, they all agreed that the situation needed to be addressed.

The learning also enabled the EU policy actors to form preferences about potential regulatory instruments to tackle the issue which also affected the inclusion of the issue into the White Paper. The Member States and the CULT Committee underlined the necessity of a holistic approach involving FIFA, UEFA and the EU institutions to address the situation of players' 
agents. They wanted FIFA and UEFA to work together to amend the licensing system and urged UEFA to reinforce the control of players' agents in European football by giving a greater care for regulatory enforcement (Arnaut 2006, European Parliament 2007a). At the same time, they also called on the DG EAC to present a proposal for the 'European directive of players' agents' which in their view was the most appropriate legislative tool to support the regulatory efforts of the football governing bodies in Europe (Arnaut 2006, pp. 220 \& 131, European Parliament, 2007a, para. 44). The calls of the Member States and the CULT Committee were particularly influential for the DG EAC to include the issue into the White Paper on Sport. Additionally, during the meeting of the ad-hoc Working Group 'White Paper', organised by the German Presidency in March 2006 and attended by 16 Member States, the Member States agreed on the necessity of placing the issue as an agenda item within the White Paper (European Commission 2007b, p. 127). Despite acknowledging the calls for the legislative proposal, the DG EAC opted for carrying out an impact assessment which was detailed under the accompanied action plan to the White Paper, the 'Pierre de Coubertin' Action Plan (European Commission 2007c). In the view of the DG EAC, it was necessary to further analyse the extent of the problem by gathering more information and to assess the impact of any potential EU action on the issue. Despite their conflicting preferences regarding instrumental tools, the inclusion of players' agents into the political agenda was significant for issue-focused and structured activities in the aftermath of the White Paper.

\section{Phase 2: Post-White Paper on Sport (2007-2010)}

The inclusion of players' agents within the White Paper increased the visibility of the issue at the European level and allowed the EU policy actors to undertake the issue-specific policy actions in the context of the impact assessment. The recognition of the issues as a policy problem shifted the focus of activities onto the analysis about the extent of the problem and the identification of an alternative regulatory solution. The DG EAC commissioned a study on the situation of sports agents in Europe in 2008 as a part of the impact assessment (KEA et al. 2009). The progression on players' agents also became a key priority for the Member States during this phase. The European Sport Ministers and Sport Directors reviewed the Member States' policy priorities under their informal rolling agenda for sport and the issue of players' agents was determined as a main priority item in relation to the organisation of sport in Europe (Council of the European Union 2008a). With a view to extend their collaborative ties with the DG EAC, the Member States also decided to maintain the ad-hoc Working Group 'White Paper' to ensure a close coordination but also to monitor the progression on the implementation of the specific action concerning the situation of players' agents (Council of the European Union 2008a, p. 1). The French Presidency, in this respect, integrated the issue into its work programme and jointly worked on the study commissioned by the DG EAC (Council of the European Union 2008b). The CULT Committee meanwhile endorsed the White Paper and the specific actions under its specific resolution (European Parliament 2008). Yet, the Committee was particularly dissatisfied with the decision of the impact assessment and, for this reason, reiterated its calls for the proposal of the EU directive on the issue.

Coinciding with the development at the European level, players' agents also became a priority agenda item for the sport actors. Their shared perceptions about the situation of players' agents and concerns about the well-being of football were underlying inner factors that influenced their respective decisions to act on the issue. The work on the improvements of the rules concerning the activities of players' agents was prioritised by UEFA because of 'the increased prevalence of agents in team sport (operating predominantly in the European 
area) and the well documented problems linked to their various activities' (UEFA 2008a, p. 13). For UEFA, the key objective of this work was 'to protect the integrity and image of team sport' (UEFA 2008a, p. 8). Concurrently, FIFA decided to conduct an in-depth reform of its licensing system as a part of the global package of football governance measures that were agreed in conjunction with the FIFPro, which, in its view, was required 'to defend the game's universality and the integrity' (FIFA 2009b). FIFA claimed that only $25 \%$ to $30 \%$ of international transfers were conducted by licensed agents and the existing licensing system was practically ineffective to deal with unlicensed agents (Villiger 2011). Therefore, FIFA agreed to commence a consultation procedure involving the stakeholders, except the EFAA, to develop a new system based on the concept of intermediaries. A sub-committee composed of the representatives of all stakeholders was established to carry out the reform work (FIFA 2014). The EFAA were consulted at a later stage in the reform process (Branco Martins, 2014).

The European study on sports agents (KEA et al. 2009) was published in December 2009. For the first time, the study developed a European outlook players' agents by evaluating the economic scale of the profession, the extent of the problems associated with their activities, and the challenges for the efficacy of the existing regulatory framework. A strong economic presence of players' agents in European football was evidenced as 'football was by far most represented sport with a highest number of agents' in comparison to other sports (KEA et al. 2009, p. 40) and players' agents were active in all 27 Member States (KEA et al. 2009, p. 35). An estimated 200 million Euros was annually paid in fees to agents for transfers in football (KEA et al. 2009, p. 55). The study also underlined the existence of unethical practices such as the dual representation of both players and clubs under the same transfer, the nondisclosure of the level of commission to players, the concealment of important information from players, and the abandonment of players after the receipt of commission (KEA et al. 2009, p. 55). More significantly, the study emphasised the conduciveness of the activities of players' agents to a number of criminal practices including money laundering, the trafficking of young players, and bribery (KEA et al. 2009, pp. 99-132). Additionally, a cross-border nature of agents' activities was deemed to be a serious impediment to the effectiveness of regulatory enforcement which in effect also contributed to the existing regulatory problems. The study therefore urged public authorities to support the regulatory efforts of the sport movement in the field and proposed the EU to take a proactive role to ensure behavioural change through harmonising existing regulatory practices and, if necessary and appropriate, to introduce regulations (KEA et al. 2009, pp. 172-176).

The CULT Committee, meanwhile, became concerned not only with the negative findings of the study but also with the possibility of de-regulation of agent market by FIFA without an alternative robust regulatory system in place (European Parliament 2010a). The Committee, therefore, wanted the DG EAC to be more proactive about the issue and, to that effect, in March 2010 presented an oral question on players' agents with a debate in the Parliament (European Parliament 2010a). During the parliamentary debate, attended by Doris Pack, then the Chair of the Committee, and Androulla Vassiliou, then the Commissioner responsible for sport, the shared perceptions of the EU actors once again were evident. According to Doris Pack, these problems were damaging the integrity of the sport and inconsistent with its social role (European Parliament 2010b) whilst Ivo Belet, the member of the Committee and the rapporteur of the parliamentary report in 2007, underlined the necessity to act on the issue 'in the interest of sport and its extremely important social role' (European Parliament 2010b). Androulla Vassiliou, stressed the importance of tackling the issue in order 'to preserve the integrity and fairness of sport competitions' (European Parliament 2010b). Following the 
debate, the Committee also adopted its specific resolution on players' agents on $17^{\text {th }}$ June 2010 (European Parliament 2010a). Talking into account the findings of the study about the unethical and criminal dimensions of players' agents' activities (European Parliament 2010a, para. 3), the Committee emphasised the importance of a coherent EU-wide approach to ensure a proper monitoring and control of the cross-border practices of players' agents (European Parliament 2010a, para. 15-17). Therefore, the Committee renewed its call to the DG EAC for the proposal of an 'EU initiative' on players' agents and also urged the Member States to step up their coordinating efforts in fighting against the criminal elements identified within their activities (European Parliament 2010a, para. 12).

\section{Phase 3: Post-Lisbon (2010-2015)}

During the aftermath of the Lisbon Treaty, the reform work that initiated by FIFA and the ongoing implementation process of the impact assessment were unified under a framework of activities at the European level. The EU policy actors perceived the situation of players' agents as a transnational challenge for European football due to the cross-border nature of activities (European Commission 2011a, Council of the European Union 2011). Therefore, the issue was deemed to be an area that an EU action can bring an added-value by developing a concerted approach involving the Member States, the DG EAC and the Presidencies which respects the regulatory autonomy of the governing bodies and the competences of the Member States in accordance with the principles of the new competency (European Commission 2011a, Council of the European Union 2011, European Parliament 2012). According to the DG EAC, an appropriate EU action in the field of sport was considered to be providing platforms for dialogues involving all parties, spreading good practices, and helping the development of European networks (European Commission 2011a). On that basis, the DG EAC decided to organise a conference on agents which took place in November 2011 bringing together the EU policy actors, FIFA, UEFA and the stakeholders to discuss possible ways to improve the regulatory framework for players' agents (European Commission 2011a). The Member States, at the same time, under the first ever EU Work Plan on Sport (Council of the European Union 2011) decided to establish the Expert Group on Good Governance to carry out the follow-up work on the conference. Both the EU conference and the meetings of the Expert Group, consequently, became critical dialogue platforms for all actors to work together on the new regulatory framework that proposed by FIFA.

The shared perceptions of the stakeholder, during this phase, concerning the negative effects of the situation of players' agents on the integrity of sport were also revealed. The ECA published a position paper outlining the priorities for cooperation at the European level which included players' agents (ECA 2011). According to the ECA, the behaviour of agents in illegitimate manner has been 'tarnishing the image of entire profession' and 'led to detrimental effects on sport and its participants including clubs and players' (ECA 2011, p. 4). During the EU conference, the EPFL representative claimed that 'the situation of players' agents posed a threat to the integrity of sport and there was a need for a robust framework to address the challenge' (European Commission 2011b, p. 2). FIFPro also complemented the reform work initiated by FIFA which has aimed to defend the integrity of football (FIFPro 2013).

Despite a general consensus on the necessity to improve the regulatory framework of players' agents, the actors' divergent views about the appropriate method of regulation became also evident during this period. At the European level, the DG EAC preferred to be a facilitator 
for dialogue but the CULT Committee asked for measures to support the regulatory efforts of the sport actors and the stakeholders. The Committee requested both the DG EAC and the Member States to take specific actions under its resolution (European Parliament 2012). The DG EAC was called to draw up and implement a 'European licensing and registration system' accompanied by a 'code of conduct' and a 'sanctioning mechanism' (European Parliament 2012, para. 75). The Member States were urged to 'supplement existing regulatory provisions governing players' agents with deterrent sanctions and to cooperate with sports governing bodies to eradicate corrupt practices' (European Parliament 2012, para. 77-78). With regards to the stakeholders, a deep division between the FIFPro and the EFAA existed. Whilst the EFAA wanted to self-regulate the profession, the FIFPro questioned the regulatory capabilities of the EFAA and therefore backed the reform process of FIFA (European Commission 2011b). Both the ECA and the EPFL also supported the new regulatory framework proposed by FIFA (European Commission 2011b). UEFA also underlined that the regulation of players' agents was a regulatory matter for FIFA but raised the possibility of a potential private-public partnership to ensure an effective enforcement of regulations (European Commission 2011b). Consequently, the actors managed to overcome some of their differences through the inclusive dialogue, in particular within the settings of the Expert Group meetings (Council of the European Union 2013). As a result, the process led to the adoption of the new FIFA Regulations on the Working with Intermediaries (FIFA 2015) which came into force on $1^{\text {st }}$ April 2015.

\section{Conclusion}

This paper has sought to explain the way socio-cultural policy making has developed over the course of the decade from 2005 to 2015. The diversity of the actors of the socio-cultural coalition and the complexity of their belief systems mean that their perceptions of basic causes of the policy problem are complex. The empirical precepts of the actors' belief systems concerning sport's integrity and economic well-being that affect its healthy development in Europe have been the primary cognitive motivators driving the socio-cultural dimension of the EU sports policy forward during this period. Consequently, the sociocultural model of sports regulation, reflecting the secondary aspects of their belief systems, has been developed through the policy framework based on the thematic policy agenda with specific policy issues and related actions. The issues that are perceived to be problems parameters that negatively impact on sport's specific characteristics in Europe, i.e., the core values of the coalition actors, have been placed into the political agenda. The issue specific analysis of the activities of the coalition actors regarding to the issue of players' agents, in this respect, illustrates the shared concerns about the detrimental effect of the situation of players' agents on the integrity of sport which in turn undermines the specificity of sport including its social role and autonomy. Therefore, the coalition actors worked together to improve the regulatory framework that governs players' agents. The new regulatory regime of FIFA based on the concept of intermediaries is the end product of this cooperation.

The analysis of the activities of the coalition actors with regards to players' agents demonstrates some of the dynamics of the socio-cultural policy making at European level. During the initial phase preceding the White Paper on Sport, there was a weak level of coordination (Zafonte and Sabatier 1998) involving repeat interactions at different dialogue platforms and the information exchange about the specific issues that affected the integrity of sport and its financial health which also included the situation of players' agents. In practice, this level of cooperation was particularly important for the EU policy actors to learn about the challenges of sport at the European level. The learning enabled them to make choices about 
items for the inclusion into the policy agenda which was originally established under the White Paper. Accordingly, this initial stage was pivotal for the establishment of the policy framework and the sport actors and the stakeholders played an important role in shaping the policy agenda by providing technical information about the specific issues. In the aftermath of the White paper and the Lisbon Treaty, the issue specific activities of the coalition actors indicate a greater level of coordination (Zafonte and Sabatier 1998). They developed closer collaborative ties and engaged in onerous policy actions (Matti and Sandstrom 2013, Stritch 2015) such as the joint policy analysis of the situation of players' agents, analytical discussions about the alternative regulatory mechanisms, and participation in meetings for policy deliberations. In practice, the policy framework certainly fosters a closer cooperation between the actors as it enables them to focus their activities on the specific issues. The prioritisation of the issue of players' agents by the EU policy actors, in particular the DG EAC and the Member State, and by FIFA and UEFA clearly contributed their synchronised actions and concerted efforts to improve the regulatory framework.

Finally, the emergence of the new FIFA regulations as an output also highlights the limitation of the EU's regulatory capacity in tackling the issues that affect sport in Europe. The soft competency in the field of sport constrains the ability of the EU to adopt hard law measures and limits its options to recommendations and incentive measures. Theoretically, this is a constitutional limitation of the EU that impacts on its resources and instrumental alternatives (Sabatier 1988). With regards to players' agents, aware of the limits of the potential EU action, the DG EAC successfully managed the expectations of the CULT Committee and the Member States in the policy process of the issue. The decision of the impact assessment under the White Paper was strategic in a sense that it was a viable option as the DG EAC could not have proposed the EU directive of players' agents as requested by the CULT Committee and the Member States due to the limited authority in the field of sport. Yet, the decision ensured the progression of activities on the issue in the aftermath of the White Paper by placing it into the agenda. Additionally, the dialogue platforms such as the EU conference and the meetings of the Expert Group allowed the coalition actors, to a certain extent, to mitigate their differences regarding to the new regulatory framework through discussions. Nevertheless, it is now emerging that the implementation of the new FIFA regulations by national associations has been so far varied and the capability of the new framework to overcome the existing problems of players' agents has been already questioned (Collucci 2016). This is a really challenging situation for the coalition actors. After all, if the policy actors are not able to address sport's challenges effectively which in turn undermine its specific characteristics, their efforts to protect their policy core will fail which can be the demise of their belief systems. Therefore, in moving forward, the soft competency can be a serious obstacle for the EU policy actors to take concrete actions to protect sport and whether dialogue, recommendations, and incentive measures can be effective to tackle sport's negative trends remains to be seen. 


\section{References}

Arnaut, J.L., 2006. Independent European Sports Review, a report by Jose Luis Arnaut.

Barke, R., 1993. Managing technological change in federal communications policy: the role of industry advisory group. In: Sabatier, P. and Jenkins-Smith, H., eds. Policy change and learning. Boulder, CO: Westview Press.

Beunanno, L., Nugent, N., 2013. Policies and policy processes of the European Union. London: Palgrave Macmillan.

Branco Martins, R., 2007. The Laurent Piau Case of the ECJ on the Status of Players' Agents. The International Sports Law Journal, 3-4, 8-12.

Branco Martins, R., 2009. The Laurent Piau Case of the ECJ on the Status of Players' Agents. In: R. Parrish, S. Gardiner and R. Seikmann, eds. EU, sport, law and policy: regulation, reregulation and representation. The Hague: TMC Asser Press, 247-258.

Branco Martins, R., 2014. The Introduction of the Social Dialogue in the European Professional Football Sector (Doctoral dissertation, Edge Hill University).

Bogusz, B., Cygan, A.J. and Szyszczak, E.M. eds., 2007. The regulation of sport in the European Union. Cheltenham: Edward Elgar Publishing.

Caiger, A. and Gardiner, S. Eds., 2000. Professional sport in the EU: regulation and reregulation. The Hague: T.M.C. Asser Press.

Collucci, M. eds., 2016. FIFA regulations on working with Intermediaries, implementation at national level ( $2^{\text {nd }}$ Edition). International Sports Law and Policy Bulletin 1/2016, Sports Law and Policy Centre Srls, Salerno, Italy.

Council of the European Union, 2007. Portuguese Presidency Conclusions from the Informal Council of Ministers of Sport of the European Union. Lisbon, 25 October 2007. Available from:

https://www.eerstekamer.nl/eu/documenteu/conclusies_informele_sportraad_en/f=/vhsxcfdh3 78w.pdf [Accessed 16 December 2016]

Council of the European Union, 2008a. Slovenian Presidency Conclusions, Informal EU Sports Directors general meeting. Brdo pri Kranjo, 4-5 February 2008. Available from: https://www.rijksoverheid.nl/binaries/rijksoverheid/documenten/kamerstukken/2008/04/14/c onclusies-van-de-voorzitter-na-informele-ontmoeting-sportministers-16-17-maart-2008/s2842231b.pdf [Accessed 18 December 2016]

Council of the European Union, 2008b. The French Presidency of the Council of the European Union work programme: Europe taking action to meet today's challenges. Available from: http://archiveue2008.fr/webdav/site/PFUE/shared/ProgrammePFUE/Programme_EN.pdf [Accessed 5 January 2017] 
Council of the European Union, 2010. Resolution on the EU structured dialogue on sport (2010/C 322/01), Brussels. Available from: http://eur-lex.europa.eu/legalcontent/EN/TXT/?uri=CELEX:32010G1127(01) [Accessed 10 August 2017]

Council of the European Union, 2011. Resolution on a European Union Work Plan for Sport for 2011-2014 (2011/C 162/01), Brussels. Available from: http://eur-lex.europa.eu/legalcontent/EN/TXT/?uri=CELEX:42011Y0601(01) [Accessed 10 November 2016]

Council of the European Union, 2013. Expert Group Good Governance - Supervision of sports agents and transfer of players, notably young ones. Available from:

http://www.sport.ee/et/file/84d80fa7238e5e786c244d7f86f45809/gg_d3_noormangijad_agen did.pdf [Accessed 16 January 2017 ]

Council of the European Union, 2014. Resolution on a European Union Work Plan for Sport for 2014-2017 (2014/C 183/03), Brussels. Available from: http://eur-lex.europa.eu/legalcontent/EN/TXT/?uri=celex\%3A42014Y0614(03) [Accessed 17 November 2016]

Council of the European Union, 2017. Resolution on a European Union Work Plan for Sport for 2017-2020 (9639/17), Brussels. Available from:

http://data.consilium.europa.eu/doc/document/ST-9639-2017-INIT/en/pdf [Accessed 25 June 2017]

Duval, A. and Van Rompuy, B. eds., 2016. The Legacy of Bosman: Revisiting the Relationship Between EU Law and Sport. Springer.

ECA, 2011. The clubs' perspective on the major issues impacting European football [online]. Available from: http://www.ecaeurope.com/Global/2/ECA\%20Position\%20Paper.pdf [Accessed 30 June 2017]

European Commission, 2006. Report: Sport Governance in Europe: White Paper Consultation by Commissioner Jan Figel with European Sport Federations. 20 September 2006. Available from: http://www.asser.nl/upload/sportslawwebroot/cms/documents/cms_sports_id73_1_figel_federations_Report_en.pdf [Accessed 10 March 2017]

European Commission, 2007a. White Paper on Sport. COM (2007) 391 final, 11 July 2007. Available from: http://eur-lex.europa.eu/legalcontent/EN/TXT/?uri=CELEX\%3A52007DC0391 [Accessed 17 November 2016]

European Commission, 2007b. The EU and sport: background and context. Accompanying document to the White Paper on Sport. SEC (2007) 935, 11 July 2007. Available from: http://eur-lex.europa.eu/legal-content/EN/TXT/?uri=CELEX\%3A52007SC0935 [Accessed 17 November 2016]

European Commission, 2007c. Action Plan Pierre De Coubertin, accompanying document to the White Paper on Sport. The Commission Staff Working Document. SEC (2007) 934. 11 July 2007. Available from: http://eur-lex.europa.eu/legalcontent/EN/TXT/?uri=CELEX:52007SC0934 [Accessed 17 November 2016]

European Commission, 2011a. Developing the European dimension in sport. COM (2011) 12 
final, January 2011. Available from: http://eur-

lex.europa.eu/LexUriServ/LexUriServ.do?uri=COM:2011:0012:FIN:en:PDF [Accessed 17 November 2016]

European Commission, 2011b. Final Report: EU Conference on Sports Agents. Available from: http://ec.europa.eu/assets/eac/sport/library/studies/final-report-eu-conference-sportsagents.pdf [Accessed 15 January 2017]

European Parliament, 2005. Sports in internal market. DG Internal Policies of the Union, Directorate A, Economic and Scientific Policy, (Project No IP/A/IMCO/ST/2005-004). Available from: http://www.asser.nl/sportslaw/research/past-research-projects/professionalsport-in-the-internal-market/professional-sport-in-the-internal-market/ [Accessed 19 November 2016]

European Parliament, 2007a. Resolution of the European Parliament on the future of professional football in Europe (2006/2130(INI)). Available from:

http://www.europarl.europa.eu/sides/getDoc.do?type=TA\&language=EN\&reference=P6-TA$\underline{\text { 2007-100 }}$ [Accessed 19 November 2016]

European Parliament, 2007b. Report on the future of professional football in Europe. Committee on Culture and Education, Rapporteur: Ivo Belet, Document A6-0036/2007. Available from:

http://www.europarl.europa.eu/sides/getDoc.do?type=REPORT\&mode=XML\&reference=A 6-2007-36\&language=EN [Accessed 19 November 2016]

European Parliament, 2007c. Annex: Why this report?, Report on the future of professional football in Europe. Committee on Culture and Education, Rapporteur: Ivo Belet, Document A6-0036/2007. Available from:

http://www.europarl.europa.eu/oeil/popups/ficheprocedure.do?lang=en\&reference=2006/213

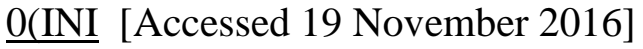

European Parliament, 2007d. The future of professional football: questions and answers. Available from:

http://www.europarl.europa.eu/oeil/popups/ficheprocedure.do?lang=en\&reference=2006/213

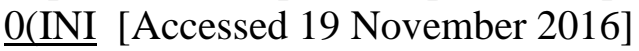

European Parliament, 2008. European Parliament resolution of 8 May 2008 on the White Paper on Sport (2007/2261(INI)) (2009/C 271 E/07). Available from:

http://www.europarl.europa.eu/sides/getDoc.do?pubRef=-//EP//TEXT+TA+P6-TA-2008-

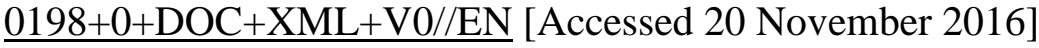

European Parliament, 2010a. Sport, especially concerning players' agents. European Parliament resolution of 17 June 2010 on players' agents in sport. P7_TA(2010)0233 (2011/C 236 E/14). Available from: http://www.europarl.europa.eu/sides/getDoc.do?pubRef=//EP//NONSGML+TA+P7-TA-2010-0233+0+DOC+PDF+V0//EN [Accessed 10 January 2017]

European Parliament, 2010b. Sport, especially concerning players’ agents (Debates). Tuesday, 15 June 2010, Strasbourg. Available from: 
http://www.europarl.europa.eu/sides/getDoc.do?type=CRE\&reference=20100615\&secondRe f=ITEM-019\&language=EN\&ring=O-2010-0032 [Accessed 10 January 2017]

European Parliament, 2012. European Parliament resolution of 2 February 2012 on the European Dimension in Sport (2011/2087(INI)). Available from:

http://www.europarl.europa.eu/sides/getDoc.do?type=TA\&language=EN\&reference=P7-TA-

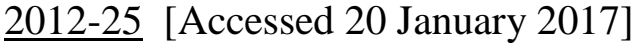

European Parliament, 2017. European Parliament resolution of 2 February 2017 on an integrated approach to Sport Policy: good governance, accessibility, integrity (2016/2143(INI)). Available from:

http://www.europarl.europa.eu/sides/getDoc.do?type=TA\&language=EN\&reference=P8-TA-

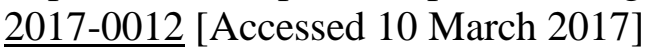

FIFA, 2007. EU White Paper on Sport: much work remains to be done [online]. Available from: http://www.fifa.com/governance/news/y=2007/m=7/news=white-paper-sport-muchwork-remains-done-550327.html [Accessed 5 July 2017]

FIFA, 2009a. Lisbon Treaty gives a boost to sport - This is also about safeguarding its integrity [online]. Available from:

http://www.fifa.com/governance/news/y=2009/m=11/news=lisbon-treaty-gives-boost-sport1141618.html [Accessed 27 June 2017]

FIFA, 2009b. 6+5, specificity of sport, players'status, etc. [online]. Available from: http://www.fifa.com/governance/news/y=2009/m=11/news=fifa-and-fifpro-agree-globalmeasures-1139271.html [Accessed 27 June 2017]

FIFA, 2014. Football as a catalyst for social change: no football without ethics and integrity [online]. Available from: http://www.fifa.com/about-fifa/news/y=2014/m=6/news=footballas-a-catalyst-for-social-change-no-football-without-ethics-an-2368340.html [Accessed 30 July 2017]

FIFA, 2015. Regulations on Working with Intermediaries [online]. Available from: https://www.fifa.com/mm/document/affederation/administration/02/36/77/63/regulationsonw orkingwithintermediariesii_neutral.pdf [Accessed 19 August 2017]

FIFPro, 2013. Agreement FIFPRO and FIFA on Package of football governance global measures [online]. Available from: https://www.fifpro.org/news/agreement-fifpro-and-fifaon-package-of-football-governance-global-measures/en/ [Accessed 15 June 2017]

Garcia, B., 2006. The Independent European Sport Review: Half Full or Half Empty. Entertainment and Sports Law Journal, 4, 1.

García, B., 2007. From regulation to governance and representation: agenda-setting and the EU's involvement in sport. Entertainment and Sports Law Journal, 5, 1.

García, B., 2008. The European Union and the governance of football: a game of levels and agendas. Thesis (PhD). Loughborough University.

García, B. and Weatherill, S., 2012. Engaging with the EU in order to minimize its impact: 
sport and the negotiation of the treaty of Lisbon. Journal of European Public Policy, 19 (2), 238-256.

García, B. and Meier, H. E., 2016. Global sport power Europe? The efficacy of the European Union in global sport regulation. Journal of Common Market Studies, 2016, 1-21.

Gardiner, S., Parrish, R. and Siekmann, R., 2009. EU, sport, law and policy: regulation, reregulation and representation. The Hague: TMC Asser Press.

Geeraert, A., Scheerder, J. and Bruyninckx, H., 2013. The governance network of European football: introducing new governance approaches to steer football at the EU level. International Journal of Sport Policy and Politics, 5(1), pp.113-132.

Geeraert, A., 2014. New EU governance modes in professional sport: enhancing throughput legitimacy. Journal of Contemporary European Research, 10, 2.

Geeraert, A., and Drieskens, E., 2015. The EU controls FIFA and UEFA: a principal-agent perspective. Journal of European Public Policy, 22(10), 1448-1466.

Geeraert, A., 2016. The EU in International Sports Governance: A Principal-Agent Perspective on EU Control of FIFA and UEFA. Basingstoke: Palgrave Macmillan

Geeraert, A. and Drieskens, E., 2017. Normative Market Europe: the EU as a force for good in international sports governance?. Journal of European Integration, 39(1), pp.79-94.

Henry, A., 2011. Power, ideology and policy network cohesion in regional planning. Policy Studies Journal, 39(3), 361-383.

International Olympics Committee, 2010. Common position of the Olympic and Sports Movement on the implementation of the new Treaty on the Functioning of the European Union (TFEU) on sport (Lisbon Treaty) [online]. Available from:

https://www.idrettsforbundet.no/globalassets/idrett/idrettsforbundet/english/common_positio n_of_the_olympic_and_sports_movement.pdf [Accessed 15 June 2017]

Jenkins-Smith, H., Nohrstedt, D., Weible, M.C., Sabatier, P.A., 2014. The advocacy coalition framework: foundations, evolution, and ongoing research. In: Sabatier, P.A., Weible M.C., eds. Theories of the policy process. Boulder, CO: Westview Press, 183-224.

KEA, CDES, EOSE, 2009. Study on sports agents in the European Union: A study commissioned by the European Commission [online]. Available from:

http://ec.europa.eu/sport/library/studies/study-sports-agents-in-eu.pdf [Accessed 19 June 2017]

Matti, S., Sandtrom, A., 2013. The defining elements of advocacy coalitions: Continuing the search for explanations for coordination and coalition structures. The Review of Policy research, 30(2), 240-257.

Parrish, R., 2003a. Sport law and policy in the European Union. Manchester: Manchester University Press. 
Parrish, R., 2003b. The politics of sports regulation in the European Union. The Journal of European Public Policy, 10(2), 246-262.

Parrish, R., 2008. Access to major events on television under European law. The Journal of Consumer Policy, 31, 79-98.

Parrish, R., Garcia, B., Miettinen, S., and Siekmann, R., 2010. The Lisbon Treaty and EU Sports Policy. Brussels: European Parliament, PE 438.607.

Parrish, R., 2011. Social dialogue in European professional football. The European Law Journal, 17(2), 213-229.

Rogulski, A., and Miettinen, S., 2009. The EU and sport: the implementation of the White Paper on Sport and future prospects. International Journal of Sport Policy, 1(3), 245-251.

Rossi, G., Semens, A. and Brocard, J.F., 2016. Sports agents and labour markets: evidence from world football. Routledge.

Sabatier, P.A., 1988. An advocacy coalition framework of policy change and the role of policy-oriented learning therein. Policy Sciences, 21, 129-68.

Jenkins-Smith, H., and Sabatier, P.A., 1993. The dynamics of policy-oriented learning. In: Sabatier, P.A., Jenkins-Smith, H., eds. 1993. Policy change and learning: advocacy coalition approach. Boulder, CO: Westview Press. 41-56.

Sabatier, P.A., Jenkins-Smith, H., eds. 1993. Policy change and learning: advocacy coalition approach. Boulder, CO: Westview Press.

Sabatier, P.A., 1993. Policy change over a decade or more. In: Sabatier, P.A., Jenkins-Smith, H., eds. 1993. Policy change and learning: advocacy coalition approach. Boulder, CO: Westview Press. 13-40.

Sabatier, P.A., 1998. The advocacy coalition framework: revisions and relevance for Europe. Journal of European Public Policy, 5(1), 98-130.

Sabatier, P.A., Jenkins-Smith, H., 1999. The advocacy coalition framework: an assessment. In: Sabatier, P.A, ed. Theories of the policy process. Boulder, CO: Westview Press. 117-166.

Sabatier, P.A., Weible, M.C., 2007. The advocacy coalition framework: innovations and clarification. In: Sabatier, P.A., ed. Theories of the policy process $\left(2^{\text {nd }}\right.$ edition). Boulder, CO: Westview Press, 189-222.

Schlager, E., 1995. Policy making and collective action: defining coalitions within the advocacy coalition framework. Policy Sciences, 28, 242-270.

Stritch, A., 2015. The advocacy coalition framework and nascent subsystems: trade union disclosure policy in Canada. Policy Studies Journal 40(4), 437-455.

Takorski, W., Steinbach, D., Petry, K., Jesse, B., 2004. Two players one goal? Sport in the European Union. Oxford: Meyer \& Meyer Sport. 
UEFA, 2005. Vision Europe, the direction and development of European football over the next decade. Nyon, Switzerland

UEFA, 2007a. Statement of the European Team Sports: EU White Paper on Sport: Much work remains to be done [online]. Available from:

http://www.uefa.com/MultimediaFiles/Download/uefa/KeyTopics/560675_DOWNLOAD.pd f [Accessed 18 July 2017]

UEFA, 2007b. Memorandum of understanding between the UEFA and the FIFPRO [online]. Available from:

http://www.uefa.com/MultimediaFiles/Download/uefa/Others/601340_DOWNLOAD.pdf

[Accessed 30 July 2017]

UEFA, 2008a. Safeguarding the heritage and team sports in Europe [online]. Available from: http://www.uefa.com/MultimediaFiles/Download/uefa/KeyTopics/560675_DOWNLOAD.pd f [Accessed 22 July 2017]

UEFA, 2008b. Memorandum of understanding between the UEFA and the ECA [online]. Available from:

http://www.uefa.com/MultimediaFiles/Download/uefa/KeyTopics/69/20/31/692031_DOWN LOAD.pdf [Accessed 25 July 2017]

UEFA, 2009. Memorandum of understanding between the UEFA and the EPFL [online]. Available from:

http://www.uefa.com/MultimediaFiles/Download/uefa/KeyTopics/88/17/84/881784_DOWN LOAD.pdf [Accessed 30 July 2017]

UEFA, 2010. UEFA's position on Article 165 of the Lisbon Treaty [online]. Available from: https://www.uefa.com/MultimediaFiles/Download/uefaorg/EuropeanUnion/01/57/91/67/1579 167_DOWNLOAD.pdf [Accessed 30 July2017]

Wallace, H., Pollack, M.A., and Young, A.R., 2015. Policy-making in the European Union. $7^{\text {th }}$ Edition, Oxford: Oxford University Press.

Weatherill, S., 2009. The influence of EU law on sport governance. In: Parrish, R., S. Gardiner, S., and Seikmann, R., eds. EU, sport, law and policy: regulation, re-regulation and representation. The Hague: TMC Asser Press, 79-100.

Weible, C. M., and Sabatier, P.A., 2005. Comparing policy networks: marine protected areas in California. The Policy Studies Journal, 33, 181-201.

Weible, C.M., 2006. An advocacy coalition framework approach to stakeholder analysis: Understanding the political context of California marine protected area policy. Journal of Public Administration Research and Theory, 17(1), pp.95-117.

Villiger, M., 2011. A new approach based on detailed discussions, Sport and Citizenship: the European social dialogue in sport, Issue 15. 
Zafonte, M., Sabatier, P.A., 1998. Shared beliefs and imposed interdependencies as determinants of ally networks in overlapping subsystems. Journal of Theoretical Politics, 10(4), 473-505. 